University of Nebraska - Lincoln

DigitalCommons@University of Nebraska - Lincoln

Faculty Publications from the Harold W. Manter Laboratory of Parasitology

2008

PRESIDENTIAL ADDRESS: NOTHING SUCCEEDS LIKE EXCESS

Steven A. Nadler

University of California - Davis, sanadler@ucdavis.edu

Follow this and additional works at: https://digitalcommons.unl.edu/parasitologyfacpubs

Part of the Parasitology Commons

Nadler, Steven A., "PRESIDENTIAL ADDRESS: NOTHING SUCCEEDS LIKE EXCESS" (2008). Faculty Publications from the Harold W. Manter Laboratory of Parasitology. 714.

https://digitalcommons.unl.edu/parasitologyfacpubs/714

This Article is brought to you for free and open access by the Parasitology, Harold W. Manter Laboratory of at DigitalCommons@University of Nebraska - Lincoln. It has been accepted for inclusion in Faculty Publications from the Harold W. Manter Laboratory of Parasitology by an authorized administrator of DigitalCommons@University of Nebraska - Lincoln. 


\title{
PRESIDENTIAL ADDRESS: NOTHING SUCCEEDS LIKE EXCESS
}

\author{
Steven A. Nadler \\ Department of Nematology, One Shields Avenue, University of California, Davis, California 95616-8668.e-mail: sanadler@ucdavis.edu
}

To the members of the American Society of Parasitologists, I offer my appreciation for the opportunity to serve as your president. When I was notified of my successful election as an officer, it brought to mind that famous remark by Adlai Stevenson who said, "In America, anybody can be president. That's one of the risks you take." So, what I initially perceived as somewhat of a risky venture, proved to be a more valuable and interesting experience than I anticipated. Let's hope that my presidential address has a similar outcome.

Before preparing my presentation, I spent time reading many ASP presidential addresses, and I'll be borrowing ideas of past presidents for my talk. Although I could try to pass off my review of these addresses under the guise of "research," I must make a couple of confessions, which just reflects my Catholic upbringing. First, I haven't always attended presidential addresses. For example, when John Oaks was delivering his presidential address at the Hawaii meeting in Kona, I was immersed in the warm waters of Kealakekua Bay, snorkeling on the coral reef. In any case, having recently read John's address made me appreciate the wisdom of publishing them in the Journal. And, second, I confess that I was uncertain about what direction I should take with this talk. And my library research did very little to clarify matters. Presidential addresses in our Society have run the gamut of topics. Some have been detailed scientific presentations akin to a rather long symposium talk (e.g., Norman Stoll's 1946 address entitled "This Wormy World"). Ruminations on the current status of our society have been the primary focus of others, and these often include a kind of "call to arms," challenging the membership to meet our anticipated needs (e.g., John Oaks' aforementioned 1998 address entitled "What Does the Millennium Have in Store for the American Society of Parasitologists?"). Several addresses have expounded on entertaining issues such as parasitologists who infect themselves or the practice of ingesting parasites for their taste and nutritional qualities. Both Lillian Mayberry (in 1996) and Robin Overstreet (in 2003) expounded on these themes. Other presentations defy easy characterization, but they might be described as eclectic explorations around the crossroads of the scientific enterprise, society, personalities, current events, and of course, parasites. Addresses that fit this description include Clay Huff's 1955 address entitled simply "Parasitism and Parasitology" and Sherwin Desser's 1995 address, entitled "Peeling the Cosmic Onion" - a title I always tend to think of instead as "Parasites in Outer Space." Now, my initial reaction to this diversity of approaches was to consider taking what I perceived to be the easier path, i.e., discussing one research topic that is within my "comfort zone" in a standard way. However, I quickly rejected this idea, not that I am overly industrious, but because the possibility of trying something novel intrigued me. So, please bear with me this afternoon as I risk working outside

\footnotetext{
* Presidential address: American Society of Parasitologists, 29 June 2008, Arlington, Texas.
}

my zone of comfort and take a somewhat meandering path as I reflect on scientific careers and our scientific society.

In his play "A Woman of No Importance," the Irish playwright Oscar Wilde wrote that "Moderation is a fatal thing, ... Nothing succeeds like excess." I took this phrase as the title of my address because I believe it applies at many levels in both our personal and professional lives, and this will be a recurrent theme throughout my talk. I would imagine that at least some of you already use this Oscar Wilde quotation. For example, when I teach evolutionary biology, I ask students to remember "nothing succeeds like excess" as a catchphrase for describing evolution by natural selection, rather than the more popular phrase "survival of the fittest", which is a somewhat tautological expression coined by Herbert Spencer, not Charles Darwin. Wilde's phrase captures the essential aspects of evolution, i.e., those individuals who leave more offspring (excess) do so because they have greater relative fitness, whereas merely surviving particular environmental challenges, while good for the individual organism, does not yield the change in gene frequencies that results from underlying heritable fitness differences. Shifting now to our professional activities, I would suggest that it is another type of excess-the focused intensity of effort and dedication in our professional lives that often leads to success in our research and teaching endeavors. This afternoon I will also try to convince you that if the American Society of Parasitologists is to continue on the path to success (rather than merely surviving), each of us is going to need to put Wilde's quotation into practice with respect to investment and involvement in society activities. If I am successful, I will convince most of you to reject the idea put forward in another very famous Oscar Wilde quotation, notably, "Duty is what one expects from others, it is not what one does oneself."

Before I delve more deeply into my views of what ASP needs from its members, I want to note that my introduction to the desire for "excess" in scientific matters was not through the theater, but instead via my graduate mentor at LSU Medical Center, Dr. Joe Miller. Joe provided all his graduate students with a copy of a commencement address by a former ASP Editor and President, Dr. Justus Mueller (Mueller, 1961). That address was entitled "From Rags to Riches, or, The Perils of a Parasitologist," and it was delivered in 1961 to the SUNY medical class, where Dr. Mueller was professor of microbiology. In this remarkable address, Justus expounded on the unexpected twists and turns in his life as a parasitologist, something that many of us can understand. For example, after completing his doctorate in 1928, he quickly came to realize that among biologists at that time, parasitologists were regarded, as he phrased it, "the pariahs of the scientific caste system." He suggests in his address that there was some question among his scientific colleagues as to whether parasitologists should be regarded as scientists. That this view was common enough would seem to be independently verified by the topic of Maurice Hall's 1932 ASP presidential address, entitled "Is Parasitology a Science?" You will be relieved to know that Dr. Hall vigorously 
defended the scientific nature of parasitology. But as it turned out, subsequent events made this unnecessary. With the outbreak of World War II, a newfound respect for our discipline was earned due to the impact of parasitic diseases on Allied troops. Or, as Mueller put it regarding his reversal of fortune, "Thus was scripture fulfilled: that the first shall be last, and the last first." But beyond this lesson about the reversibility of the scientific pecking order, Mueller's commencement address emphasized both the substantial dedication of effort and the moral responsibility of scientists to confront the societal issues stemming from scientific progress. With his emphasis on dedication, his address could have been subtitled with a phrase he used: "Its no good unless you sweat." His argument to these young physicians was that it is only through the challenge of obsessively pursuing perfection that individuals reach their greatest potential. Now, before I go further, I want to dispel the notion that I am advocating that scientists must be so dedicated and all consumed by their jobs that they suffer from what has been termed a professional deformation. Basically, the idea that a scientist's world-view becomes so skewed by a narrowed scientific focus that it precludes understanding perspectives shared more broadly within the larger society. And although it is difficult, I believe it is possible to have reasonably balanced personal and professional lives as we "sweat" in our quest for achievement and responsibility to both.

Now, we all accept that "excess" in research effort is commonplace among scientists, so I will not need to illustrate this point with many examples. Yet, I imagine that if I asked each of your spouses, they could provide me with some fairly entertaining examples of your individual research excesses-examples that today might even seem humorous in hindsight. I remember that when I was a postdoc at LSU, my wife Angie and I would go to the lab late at night to develop sequence autoradiographs, in the days when sequencing was still done using radioisotopes. A few years later, as a young assistant professor, I was still making those late night or early morning trips to develop X-ray films, long after the novelty of observing them wore off for Angie. Or then again, perhaps she stayed home due to my response when sequencing reactions did not work right. Now, trying to explain to my midwestern neighbors that I wasn't paid overtime for all the excessive and strange hours that I worked just brought puzzled looks and quiet nods of their heads. But, like for many of you, this research work ethic was instilled in me by the example of my mentor, whose main research tool was the electron microscope. As one example, I remember Joe Miller telling me that when the first commercial electron microscope became available from RCA, the single instrument that was purchased by LSU Medical Center was scheduled for use $24 / 7$ by lottery. So, during some weeks, you might have two hours of scope time from 3 to 5 a.m. on a weekend. Now, I truly believe there must be some classical conditioning at work here, not unlike like Pavlov's famous dogs. But, instead of salivating at the ring of a bell, our conditioned stimulus might be the sight of new types of scientific equipment, or a promising Call for Proposal, or even observing an X-ray film with beautiful sequences at 2 in the morning. Arguably, this drive for research excess is best summarized in the last words of Alexander Graham Bell: "So little done, so much to do."

No doubt because the majority of our members are academ- ics, it will take little additional effort to convince you that "nothing succeeds like excess" applies to our jobs of teaching and service. I trust that the graduate students who are here today have already been introduced to this idea, or if you have not, you may be in for a rude awakening if you thought that the tasks of a tenured academic scientist require only 40 hours per week. Now a fairly common idea is that the most successful academic scientists are like good jugglers, keeping "objects" representing our 3 primary responsibilities of research, teaching, and service, constantly rotating through the air. However, in my experience this is not a good simile at all. The most successful academics find a way to benignly neglect and hide away 2 of these 3 "objectives" at any one time while, of course, denying any such thing to inquiring administrators. They focus their attention and effort exclusively on one area. It's more like what Jack Palance's character "Curly" said in the movie "City Slickers": "One thing. Just one thing." Or, in our case, we do not quite have that luxury, so perhaps more like, just 2 of 3 things at any one time. And how do we choose which thing to focus on? Well, as Curly said in that film, "That's what you have to find out." Now, given that we all understand that academic scientists hold the equivalent of 2 full-time jobs, running a research lab plus our teaching responsibilities, it might take some convincing to explain why that "one thing" should at times be service to the ASP, particularly when service is the "ball" that is easiest to hide. This requires us to think about the value-added benefits of our ASP membership, and perhaps what our careers would be like without this Society. So, to continue with my film metaphors, we should think of ASP as the "Bailey Building and Loan" in the movie "It's a Wonderful Life." And, like the conclusion of that film, it is time for the members to reinvest in our institution.

In his presidential address, Sherwin Desser referred to the ASP as "this precious Society." Certainly one way that this is true is in the many roles that the ASP serves in the development of our individual careers. Although we might not often dwell on it, those of us who are established faculty owe much to this Society and its members. There are many ways that our members derive career benefits from the current activities of ASP. For example, our meetings provide a supportive environment for graduate students and postdocs to present research findings and build their professional skills. And, our annual meetings are an incredible living storehouse of parasitological information that provides an unparalleled resource for planning new research and forging new collaborations. Imagine, if you will, if there was an Internet search engine that could deliver the integrated information content that you can obtain in talking with colleagues here at our annual meeting! Many of your ASP colleagues provide the critical and constructive reviews to improve your manuscripts and grant proposals, and these same individuals are called upon to write letters of evaluation for your tenure and promotion decisions, serving to interpret the impact that your research has within our discipline, and thus informing your voting departmental colleagues. All of us have clearly benefited from these and additional society activities. In this sense, focusing your service efforts on ASP provides benefit to each of us individually, and to the membership as a whole. I would suggest that as our society has become smaller, the responsibility falls on each of the remaining members to ensure that ASP remains vibrant by prioritizing service to our 
society. As John Oaks said in his presidential address, "It is your willingness to be active, to take your turn, that allows this Society to exist and enables this Society to be respected, well known, and prepared for the future. The greatest risk of all to the ASP is apathy! The greatest opportunity for ASP in the years to come is to have you serve." And, although I hesitate to pick out some examples because of deserving individuals that I will omit, ask yourself where our Society would be without the recent volunteer contributions of Drs. Lillian Mayberry, George Cain, John Janovy, Jr., Don Duszynski, or Jerry Esch? These are "big shoes to fill," but ASP needs members who are willing to step up and try.

I want to turn now to a bit of prognostication about ASP, something that many former presidents have attempted. One of my favorite quotations involves this topic-predicting the future and the contingencies of history. The American novelist and critic, Gore Vidal, was once asked what he thought would have happened in 1963 if Khrushchev and not Kennedy had been assassinated. His response was "with history one can never be certain, but I think I can safely say that Aristotle Onassis would not have married Mrs. Khrushchev." So, I am hoping that today I can share in this special insight of Mr. Vidal, where if I cannot actually predict the future, at least I can rule out some possibilities that represent figurative marriages of "Onassis and Krushchev."

Although we might want to deny it, I believe one of the things we can rule out for the immediate future is growth in our Society's membership. At our peak in 1975, we had 1,946 members. In 2007, we had 814 members and that represents a $48 \%$ decrease since 1994 when we still had 1,571 members. Of perhaps greater concern is that we had only 116 student members in 2007. Numbers for 2008 are similar; we now have 817 total members, including slightly more student members. Our membership demographics are also not in our favor, as pastpresidents have discussed in some detail. For example, in the 2005 survey of ASP members, approximately 55\% of respondents were age $50 \mathrm{yr}$ and older, with all the younger age cohorts showing decreases, as a percentage of membership, between the 1992 and 2005 surveys. I don't know of any evidence to suggest that our membership numbers have yet stabilized, and our number of regular members has continued to decline in every recent year. I note that our newly elected vice president, who is among the most optimistic and enthusiastic persons that I know, proclaimed in her election agenda statement "I believe we should accept that we have now reached our new optimal level of membership. Let the Society now enthusiastically and aggressively move forward in its new, sleeker, form to ensure no further decline!" Ensuring no further decline is going to require recruiting and retaining new (younger) members at a much higher rate than we have recently, given that student membership averaged 159 between 1984 and 2000, and this was insufficient to prevent our current situation. Likewise, during our peak growth years in the early 1970s, we averaged 120 new members per year, or almost $7 \%$ of the total membership (the range from 1966 to 1975 was 5-10\% new members per year). Given our current membership, $7 \%$ member recruitment would be roughly 57 new members per year. By making some projections about yearly recruitment and using more accurate data on our demographics, we could do some modeling about when and at what size we may stabilize; perhaps the member- ship committee would be willing to undertake this project. However, not being inclined to try this myself, Dr. Caira's statement about a new "sleeker form" peaked my interest in learning more about when during the history of ASP we were of similar size. As it turns out, from our founding in 1924 with 321 charter members, until 1950, ASP had 800 or fewer members (779 in 1950) - and it wasn't until 1959 that our society reached 1,000 members. That means that for approximately half of our existence, we have been a society of less than 1,000 members, i.e., of "sleeker form". Also by comparison, for the 1950 annual meeting when we had roughly the same number of members as today, 120 papers were presented, whereas 148 papers are being presented here in Arlington. My point is that ASP was a vibrant scientific society before we grew large, and we remain one today, even with reduced membership. Now do not get me wrong, I believe we must continue every effort to recruit new members. However, I find myself agreeing with Dr. Caira in that I don't think we should panic if membership continues to decline in the immediate future, as long as our eventual equilibrium allows us to sustain our core functions of the Journal and our annual meeting. One might be tempted to think that the greatest risk of being small is for the financial aspects of the society. Indeed, the treasurer's report for 1925 indicated $\$ 320.56$ in expenditures and $\$ 321.45$ in receipts, leaving a balance of 89 cents. In 1950, the society spent $68 \%$ of its receipts, leaving a balance of $\$ 6,984$. So, it stands to reason that we must have done great in 1975 when our membership was at its peak? Well, in that year we spent $97 \%$ of receipts, leaving a balance of just $\$ 3,362$. Although these are only limited snapshots of our fiscal performance, I think we can dispense with the notion that increased membership necessarily translates into financial soundness. Much depends on our expenditures, the two greatest of which are the Journal and the annual meeting. Although it is too early to know, the ASP Council is hopeful that our recent 5-yr Allen Press agreement will not only eliminate our costs for journal expenses but also may yield substantial royalties that can be used to support our other needs.

I have one other "marriage of Onassis and Krushchev" to discuss, and that is the idea that we can retain all of our current committees given our sleeker form. According to my rough tabulations, ASP has 36 committees requiring 131 member positions, not including fixed officer appointments that are assigned to some committees. Twenty of these committees are standing committees that are defined in our bylaws and require 92 member positions; 16 are special or ad hoc committees that require 46 positions (and not all special committees are even filled). Although I'm sure that all these committees were created to address issues deemed of high priority at their inception, I think we must accept that in operating a volunteer organization with fewer members, we will need to focus our committee activities on our most essential functions. I am pleased to report that this year's ASP Council has begun addressing this issue by eliminating some committees at my request. It is also instructive that when compared to our similar sized membership from the 1950 s, we currently have approximately 5 times as many committees. The sheer number of ASP committee positions presents a problem for the president, who has to appoint these committee members. I estimate that today's members are probably 5 times as likely to say no to a request to serve than back in the days when suits and ties were the normal dress at these meetings. 
Other recent ASP presidents have also experienced this refusal of members to serve on committees or even accept the honor of being nominated for elective office. As Past-President Steve Kayes noted about this problem, "everyone has too much on their plate, and everyone else is wound too tightly." That said, I think that if we were able to time-travel back to 1950 , our post-war ASP members would feel that their "plates" were piled pretty high. Instead, I suspect that something was different in that generation's collective view of the value and priority of such service. Perhaps because many members of that era had recently served in the military, they were more conditioned to "volunteering," or simply taking orders. Whatever the causes, some of our current members are going to need to find renewed motivation for society service. Now I must emphasize there are already numerous ASP members, both young and old, that have a long history of this type of volunteer effort; one example are individuals who serve as associate editors of the Journal, and our Society owes these and other such individuals our gratitude.

I must admit that I've had some fun today with the liberal use of quotations. So, it seems only fitting that I bring my talk to a close by making more use of the words of former ASP presidents. Their presidential addresses contain many valuable, timeless insights into the challenges and opportunities for our members, and most of the points I have tried to make today have already been covered by past-presidents. Ten years ago in his presidential address (the one I missed while snorkeling), John Oaks referred to principles of the ASP that were outcomes of developing our mission and vision statements. These ASP statements were published in Volume 19 of the Newsletter, but because a decade has passed, this is an opportune time to revisit them. Our mission includes the following:

1. constantly improving our understanding of parasitic diseases and parasitism;

2. providing opportunities for all scientists to publish original findings in the Journal;
3. providing venues for presenting and discussing new scientific information; and

4. remaining a strong focus of scientific exchange across the broader discipline by seeking out and supporting new research areas and members, while simultaneously maintaining our base in current specializations.

These are laudable goals for our society to be mindful of, and pursue, with respect to research, teaching, service, and outreach. However, we risk that these goals will not be achieved unless more of our members get involved. To paraphrase Justus Mueller, we won't be very good unless more of us sweat on behalf of the society. Or, as phrased much more eloquently by former ASP President Martin Ulmer, "The common good of any scientific society lies with its members, and it follows that the greater the degree of their responsible participation, the greater the likelihood of the continued health of the organization." I think it would be hard to say it any better than that. So, it's time for our remaining members to ask themselves whether they truly feel strongly enough about preserving our special society to take the necessary actions. Indeed, "That's what you have to find out."

Thank you for the honor of serving as your president and for your attention this afternoon.

\section{ACKNOWLEDGMENTS}

I thank the officers, Council members, and committee members of ASP for active participation in Society business during my term as president. Special thanks go to Dr. John Janovy, Jr., and his assistant Beth Wilkins for service to the Society in the secretary-treasurer's office. I owe many colleagues for sharing special insights that have shaped my scientific world-view, but none more so than my dissertation mentors, Drs. Joe Miller and Herb Dessauer.

\section{LITERATURE CITED}

Mueller, J. F. 1961. From rags to riches, or, the perils of a parasitologist. The New Physician 10: 272-276. 